\title{
Discernment of Pitfalls in Understanding Finite and Non-Finite Verb Structures by English Language Learners
}

\author{
Muhammad Ali Shahid ${ }^{1}$ (D) $\triangle$, Anser Mahmood ${ }^{2}$ (iD, Rana Muhammad Basharat Saeed ${ }^{3}$ \& (D), Muhammad \\ Shaffaqat ${ }^{4}$ (D) and Gulshan $\mathrm{Naz}^{5}$ \& \\ ${ }^{1}$ Principal, the Hope College of Science \& Management, Sillanwali, Pakistan \\ ${ }^{2} H O D$, English Literature and Linguistics the University of Lahore, Sargodha Campus, Sargodha \\ ${ }^{345}$ Scholar, the University of Lahore, Sargodha Campus
}

$\triangle$ Corresponding Author: Muahamad Ali Shahid, E-mail: muhammadalishahid05@gmail.com

\author{
ARTICLE INFORMATION \\ Received: April 15, 2021 \\ Accepted: May 25, 2021 \\ Volume: 3 \\ Issue: 5 \\ DOI: 10.32996/jhsss.2021.3.5.5
}

\section{KEYWORDS}

Finite and Non-Finite Verb Structures, Linguistic Morphology, Syntactic Functions, Sentential Semantics, Linguistic Competence Level, McNemar Test Process,

Paired Samples T-test, and APA 6th Edition

\section{ABSTRACT}

The current study was conducted to investigate the "Discernment of Pitfalls in Understanding Finite and Non-Finite Verb Structures by English Language Learners." Data was collected for this purpose from 200 English Language Learners of Intermediate Level at the Hope College of Science \& Management, Garden Town Sillanwali, Sargodha Division, Punjab (Pakistan). To achieve the research objectives, the variables were interpreted using three theories: "Linguistic Morphology (Bauer, 2003)," "Syntactic Functions (Jong-Bok Kim and Peter Sells, 2007)," and "The Principle of Semantic Compositionality (Gottlob Frege, 1953)." An experimental approach was used to collect quantitative primary data, with McNemar Test Conduction in two stages: Pre-Test and Post-Test. Convenience sampling techniques were used to collect data. A six-week treatment was carried out to determine the range between two extreme Tests. The mean difference in linguistic competence was 64.69434. P-Values (Probability Values) 000 demonstrated that the Null hypothesis was rejected and the Alternate Hypothesis was accepted. It meant that the English Language Learners did exceptionally well following the teaching intervention. IBM SPSS Statistics was used to analyze the data. The entire project was formatted in APA (American Psychological Association) Sixth Edition formatting style.

\section{Introduction}

This study investigated the pitfalls in understanding finite and non-finite verb structures, systems to adapt to these pitfalls, and the linguistic competence level of Intermediate English Language Learners. "Linguistic competence is the capacity of the native speakers about language use with dominance, the ability of the structures of language calculated legitimate relations, and the usage of the language in the veritable situation by communicators," according to Avram Noam Chomsky (Malik, 2010-11). The research was based on aspects of linguistic competence. The centre segments of language structure are phonetics, phonology, morphology, syntax, and semantics, and these were remembered for a speaker's linguistic competence. The current study's point of convergence was the morphology of finite and non-finite verb structures, their syntactic harming in the sentence, and, finally, the semantic estimation of the sentence.

\subsection{Statement of Problem}

Learners of the English language face numerous complexities when it comes to forming new words, positioning, and comprehending finite and non-finite structures in sentences. In their struggle to actively master the English language, they believe that verb structures are critical to making the learners' sense of the sentence clear and understandable. The researcher used an interdisciplinary approach in this study, integrating morphology, syntax, and semantics into a compact whole; morphology of finite and non-finite verbs, their position in the sentence, and discourse semantics.

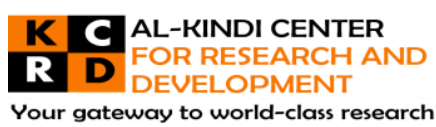

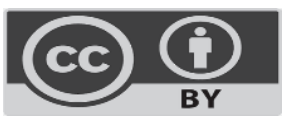

Published by Al-Kindi Center for Research and Development. Copyright (c) the author(s). This open access article is distributed under a Creative Commons Attribution (CC-BY) 4.0 license 


\subsection{Null Hypothesis}

$\mathrm{HO}=$ There is no significant difference between the Mean Scores of Pretest and Posttest of the English Language Learners. That is $\mu 1=\mu 2$

\subsection{The Research Question}

How can the present study develop the competence level of English Language Learners?

\subsection{T-Test}

Two samples T-test (also known as Paired T-Test) was used to process the data for conclusions. William Sealy Gosset (18761937), born in Canterbury, England, was inspired by true events. He interacted with Pearson, and later with Fisher and Neyman. Gosset distributed a few significant papers on statistical issues under the pen name "Student." As a result, the test became known as the "Student t-test" rather than Gosset's t-test.

\subsection{Purpose of $t$-test}

The T-test seeks to uncover the significant difference between the two types of data. The conclusion of the data tells us whether the data is significant or not.

\subsection{Critical Value}

The critical value in the t-test is the probability value ( $\mathrm{P}$-value $=.05)$. In this case, the significant value should be 0.05 . This demonstrates that there is a $5 \%$ chance that information is random and a $95 \%$ chance that information is significant.

\subsection{Treatment Schedule}

\begin{tabular}{|c|c|c|c|c|c|c|c|}
\hline Days & Monday & Tuesday & Wednesday & Thursday & Friday & \multicolumn{2}{|c|}{ Saturday } \\
\hline $\begin{array}{c}\text { Weeks } \\
\square\end{array}$ & \multicolumn{4}{|c|}{ Teaching Days } & & $\begin{array}{c}\text { Class } \\
\text { Assignment }\end{array}$ & $\begin{array}{c}\text { Home } \\
\text { Assignment }\end{array}$ \\
\hline 1. & Verb & Activity 1 & Forms of Verb & Activity 2 & & Activity 3 & Activity 4 \\
\hline 2. & $\begin{array}{l}\text { To be } \\
\text { Form }\end{array}$ & Activity 5 & $\begin{array}{l}\text { Concept of } \\
\text { Verb: Mood } \\
\text { Systems }\end{array}$ & Activity 6 & & Activity 7 & Activity 8 \\
\hline 3. & $\begin{array}{c}\text { Finite } \\
\text { and } \\
\text { Non- } \\
\text { finite } \\
\text { Verbs }\end{array}$ & Activity 9 & $\begin{array}{l}\text { Kinds of Non- } \\
\text { finite Verbs }\end{array}$ & Activity 10 & & Activity 11 & Activity 12 \\
\hline 4. & $\begin{array}{l}\text { Infinitiv } \\
\text { es and } \\
\text { Formati } \\
\text { on }\end{array}$ & Activity 13 & $\begin{array}{l}\text { Types and } \\
\text { Functions }\end{array}$ & Activity 14 & & Activity 15 & Activity 16 \\
\hline 5. & $\begin{array}{l}\text { Gerunds } \\
\text { and } \\
\text { Formati } \\
\text { on }\end{array}$ & Activity 17 & $\begin{array}{l}\text { Types and } \\
\text { Functions }\end{array}$ & Activity 18 & & Activity 19 & Activity 20 \\
\hline 6. & $\begin{array}{l}\text { Participl } \\
\text { es and } \\
\text { Formati } \\
\text { on }\end{array}$ & Activity 21 & $\begin{array}{l}\text { Types and } \\
\text { Functions }\end{array}$ & Activity 22 & & Activity 23 & Activity 24 \\
\hline
\end{tabular}

\section{Literature Review}

A Literature Review is a survey of everything that has been mentioned in the description of a specific topic, research questions, or theoretical framework (Allyson Skene). The evaluations of literature scholarly studies written by previous writers and researchers concerning the current study direct the research in the right direction. What he did was worthwhile in the same way that others did to impress the readership with existing and reasonable knowledge.

According to Close (1977), an "ing" word functions on three levels: as a subject, as an article, as a supplement, and as the object of a relational word. It is commonly stated that the non-limited conditions are generally used as the subject of the sentence's primary action word (Frank, 1972). For instance, having tea with the best companion in the bistro makes a good impression. Swan appears on the scene under the banner of a case that "-ing participle" has the potential to be used in two different 
ecological settings of sentences. When the descriptive word statement gives the possessive significance in the sentence from the start, this condition manifests itself by seeing, for example, "action words in provisos be + V - ing."

George (1990) asserts vehemently that the "ing" word functions as or like a thing and is derived from the action word's base type. He goes on to say that the "ing" word is a combination of - ing and the base type of the action word. It is used as a thing and has the same basic structure as the present participle. Regardless, the elements of the "ing" word and the present participle in the sentences are opposed. An "ing" word is always appropriate in any position.

According to Belicek (1994), "verbal modifiers" present a classification of word-assortment on the limit between participles and descriptors. Participles have the same qualities as descriptive words. The verbal character of the participles is distinguished by their ability to have accusative items: a laborious task.

Susanne Wurmbrand (1998) completes a study on "Infinitives." It is "a paper submitted to the Department of Linguistics and Philosophy at the Massachusetts Institute of Technology in Partial Fulfillment of the Requirements for the Degree of Doctor of Philosophy." The researcher examines the structure of control infinitives, the component of control, and the overall engineering of the provisions, including helper action words and modals action words, in this exposition. This paper puts to the test the claim that CP uniformly typifies control infinitives: Clausal Structure. It welcomes a firm argument that control infinitives of a specific, well-explained class are overwhelmingly broken down as simple VP-supplements that are unrelated to an implanted subject. The VP-structure supplement is driven by five arrangements of properties that are systematically distinct from the properties of clausal control of infinitives.

Board (1981), Plag (1998 and 1999), Ryder (1999), and Monternini (2002) advance the theory that word-class data is fundamental to word-arrangement rules, which has - in some form or another - been advanced previously but has never been thoroughly examined in more elaboration or across larger arrangements of attaches.

Crowley (2002) provides a comprehensive explanation of the geography of the various structures of the sequential action word arrangements shown in the Oceanic Languages. Brill and Ozanne-Rivierre propose expositions with the language described by some sequential action word developments, such as Naess's (2002) portrayal of sequential action word development in VaeakauTaumako which information has been contrasted with points in Aiwoo.

Hornova (2003) maintains the notion that non-finite Verb Structure is the one that is used as a component of an action word state, such as a determiner, and so on. The - ing structure is occasionally used to represent the action word's current participle structure. Participle phrases are the unpredictable structures of participles that can be seen in language classifications such as perspective and voice. For example, have been singing.... - great and dynamic perspective, have been singing.... - impeccable perspective and aloof voice

Margetts (2005) worked on depicting the dispersion and capability of various types of action words consolidated in atomic layer sequential action word developments about positional spaces. He demonstrated and applies it to the depiction of action words linked in atomic layer sequential action word developments in Aiwoo.

Harper (2006) enters the scene with the idea that the "ing" word as a subject represents a living personality, but depending on the circumstances, it assigns out cold characters of theoretical thoughts. The subject is accepted or found in another part of the sentence in a large number of "ing" word states, explicitly those working as objects of action words or relational words.

According to Harper (2006), when any action word is used as the article in a prepositional expression, it is expected to be of the type of an "ing" word. Many "ing" word phrases following relational words are subject-less, especially those in verb-modifying prepositional expressions.

According to Hornsby (2007), the current participle is a presumption that word morphology, mix, or the fundamental action word and - ing toward the end. The -ing participle is used as an example: a constituent of a dynamic perspective preceded by "to be": the superintendent is calling the children. B. a sentence condenser: on my way home, I ran into my companion. C. a high level of quality: a streaming stream, D. an item supplement: I saw the defender receiving the ball.

Katrine Menzel (2010) researched "Distinguishing English Gerunds and their Translation Equivalent in English German Translation Corpus." He guarantees in this research work that an "ing" word is an identity of English and that it's proportional in German Grammar cannot be found. It has ostensible as well as verbal properties. This hypothesis is to see the most widely observed frameworks that go between us in various printed registers for making an understanding of "ing" words into Germa by giving a beneficial examination of corpus sections containing "ing" words that are seen by methods for corpus requests and by separating their frequencies and their German associates in an English-German getting corpus. 
In her study "The English Gerund Vs The to-infinitive: The Case of Aspectual Constructions," Kaleta (2012) proposes the concern with complementation examples of four aspectual action words, such as start, start, proceed, and stop, each of which is concurrent with two types of non-limited complementizers - the "ing" word and the to-infinitive. The study confirms that sets of developments with the same lattice action word do not imply discretionary variations but are semantically roused. The primary goal of this commitment is to shed light on the schematic semantics of gerundive and infinitival supplements and then represent the convincing idea of their appropriation.

Pushpa Dewy (2016) directed a research study titled "An Analysis of Gerund and To-infinitive in Jakarta Post Articles." This study looks at the different types of "ing" words and to-infinitives in the Jakarta Post's game articles. The study's goal is to research and filter through the types of "ing" words and to-infinitives that appear the most in Jakarta Post articles.

Infinitives and Gerunds in Recent English: Studies on Non-finite Complements with Data from Large Corpora" was written by Juhani Rudanko (2017). These elements can be found in the book's content: 1. Nonfinite Complements of Verbs, 2. Nonfinite Complements of Adjective Subjects in American English, 3. The Semantics of To-Infinitives and -ing Complements, and 4. Lexicosyntactic Creativity in American Soap Operas

Numerous researchers have attempted to classify Finite and Nonfinite Clauses, but no work has ever been done on Finite and Nonfinite Verb Structures in tandem. This research gap prompted additional research into these action word structures' morphological, syntactic, and semantic properties. Excited by the increasing importance of Finite and Non-finite Verb Structures in understanding syntactic sentences and making them clear in sentences, the study raised the possibility of attempting it with English Learners at the Intermediate Level.

\section{Methodology}

The current study used an experimental approach and was quantitative. The methods and procedures used by the researcher for data collection and analysis are listed below.

\subsection{Data Collection}

The McNemar Test Process (pre-test and post-test) was used as a tool to collect sufficient and primary data to meet the study's objectives. The current study was conducted in the experimental design domain. The McNemar test was used to gather primary data for research purposes. Because this study takes a quantitative approach to methodology, the McNemar test was the best choice. The primary goal of this test was to obtain truth-based knowledge both before and after the test. "The time between the pretest and the posttest is referred to as the intervention or treatment period. After the treatment, there is a significant change in the motivation of the participants that can be measured. The data gathered through tests are then graded on a predetermined scale (Salkind, 2010; Siegel \& Castellan, 1998) "...

\subsection{Calculated Means of Pretest \& Posttest}

\begin{tabular}{|c|c|c|}
\hline Serial & Pretest & Posttest \\
\hline 1. & 24.9000 & 83.5000 \\
\hline 2. & 22.5000 & 90.6000 \\
\hline 3. & 19.1000 & 84.7000 \\
\hline 4. & 17.5000 & 87.1667 \\
\hline 5. & 22.5000 & 87.3333 \\
\hline 6. & 28.1000 & 86.6667 \\
\hline 7. & 28.9000 & 88.5000 \\
\hline 8. & 18.9375 & 81.1875 \\
\hline 9. & 15.0833 & 91.7100 \\
\hline 10. & 21.7000 & 84.8000 \\
\hline
\end{tabular}

\section{Data Analysis and Interpretation}

As stated by F.F. Whitney: The purpose of data interpretation is to discover the genuine and intelligent significance of the information available to meet the objectives of the study, of the part, or the topic involved. The current study's data were processed in SPSS using a t-test. To compare two means values from the same subject, a paired-samples t-test is used. The paired samples T-test compares the means of two samples from the same subject. In the current study, the samples were the observations before and after the instructing and educating treatments. 
Table 1: Paired Samples Statistics

\begin{tabular}{lccccc}
\hline \hline & & Mean & $\mathrm{N}$ & Std. Deviation & Std. Error Mean \\
\hline \multirow{2}{*}{ Pair 1 } & Pretest & 21.9221 & 10 & 4.46765 & 1.41279 \\
& & & & & \\
& Posttest & 86.6164 & 10 & 3.20309 & 1.01290 \\
\hline \hline
\end{tabular}

The descriptive statistics table displays the mean values, the number of observations, standard deviation, and standard error of Pretest and Posttest.

Table 2: Paired Samples Correlations

\begin{tabular}{|c|c|c|c|c|}
\hline & & $\mathrm{N}$ & Correlation & Sig. \\
\hline Pair 1 & Pretest \& Posttest & 10 & -.065 & .859 \\
\hline
\end{tabular}

The paired samples correlation table explains the relationship between pretest and posttest scores. This section has no weightage in the t-test. As a result, regardless of the correlation value, we should be unconcerned.

Table 3: Paired Samples Test

\begin{tabular}{|c|c|c|c|c|c|c|c|c|c|}
\hline & & \multicolumn{5}{|c|}{ Paired Differences } & \multirow[t]{3}{*}{$\mathrm{T}$} & \multirow[t]{3}{*}{$d f$} & \multirow{3}{*}{$\begin{array}{l}\text { Sig. }(2- \\
\text { tailed })\end{array}$} \\
\hline & & \multirow[t]{2}{*}{ Mean } & \multirow[t]{2}{*}{$\begin{array}{l}\text { Std. } \\
\text { Deviation }\end{array}$} & \multirow[t]{2}{*}{$\begin{array}{l}\text { Std. Error } \\
\text { Mean }\end{array}$} & \multicolumn{2}{|c|}{$\begin{array}{l}95 \% \text { Confidence Interval of } \\
\text { the Difference }\end{array}$} & & & \\
\hline & & & & & Lower & Upper & & & \\
\hline \multirow[b]{2}{*}{ Pair 1} & Pretest & & & & & & & & \\
\hline & $\begin{array}{c}\& \\
\text { Posttest }\end{array}$ & -64.69434 & 5.66374 & 1.79103 & -68.74594 & -60.64274 & -36.121 & 9 & .000 \\
\hline
\end{tabular}

i. Finally, the inferential statistic required for the paired samples t-test I is included in this table. It displays the mean difference, which is "21.9221 - $86.6164=-64.69434$." Because the mean score of the posttest is abstracted from the mean score of the pretest by "system default" in the IMB SPSS Software, the sign minus is not visible here. Because the posttest's mean score is higher, the answer is denoted by a minus sign.

ii. $\quad$ ii. The standard deviation and standard error mean values are "5.66374" and "1.79103," respectively.

iii.

iv. $\quad$ iii. The difference's confidence interval is 95. (The lowest and highest values are "-68.74594" and "-60.64274," respectively.)

v. ' $t$ ' has a value of -36.121 .

vi. The number of degrees of freedom is nine.

vii. The Prob value is the most important aspect of the t-test. The P-value (Probability Value) denoted by "Sig. (2-tailed)" is 0.000 , which is greater than 0.05. In the current study, a significant 2-tailed Prob value indicates that treatment significantly affects English Language Learners. As a result, we reject the Null Hypothesis and accept the Alternate Hypothesis. For example, there is a significant difference between the Mean Pretest and Posttest Scores of English Language Learners. That is $\mu 1 \neq \mu 2$ 


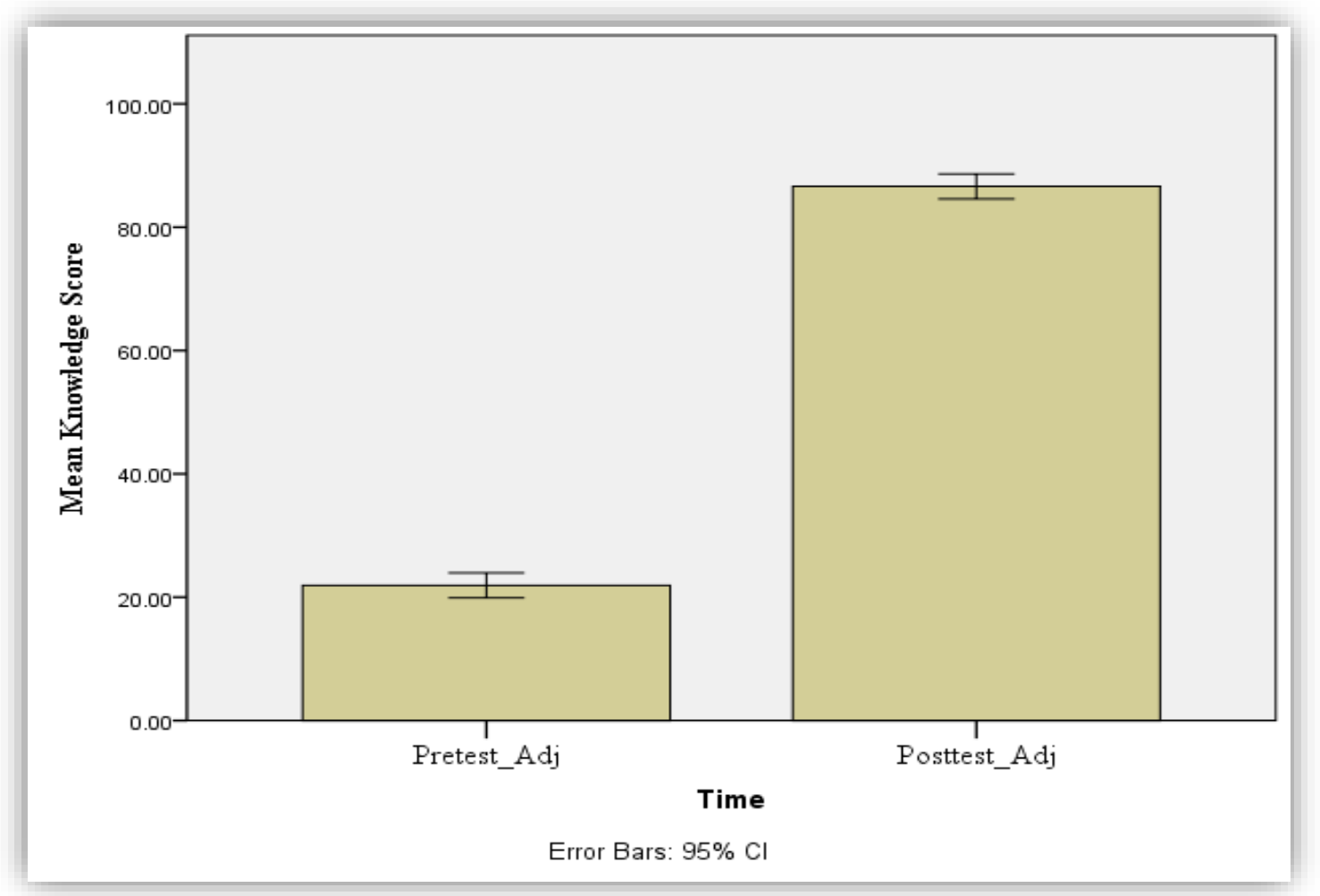

- The table's mean comparison yields the following result.

- The y-Mean axis's Knowledge Score depicts the frequency of mean value.

- The posttest bar's upper height emphasizes the significant difference from the pretest mean score. The error bars on the $x-$ axis represent the difference between the Means Scores of the Pretest and Posttest.

- The difference in means between Pretest and Posttest is: "21.9221 - 86.6164 = -64.69434."

- The treatment period is defined by time.

- The table's outcome suggests that we can reject the invalid hypothesis (the Null Hypothesis) and accept the alternative theory (the Alternate Hypothesis).

- After the teaching treatment, English Language Learners' competence level was comparatively higher and stronger in the posttest.

\section{Discussion}

The study's problem determines how English Language Learners could discern pitfalls in understanding finite and nonfinite verb structures, make proper syntactic use of them, and understand and produce meaningful and grammatically correct sentences.

According to the study's findings, English Language Learners' abilities and competence level progressively improved. They became efficient enough over time to distinguish between different forms and types of these finite and nonfinite verb structures. By applying sentential rules of structure and meaning, learners gain proficiency in making good use of these verb structures. The extent to which they attained competence level is obvious and is discussed further below in the description of inferential statistics.

According to the study's findings, English Language Learners' abilities and competence level progressively improved. They became efficient enough over time to distinguish between different forms and types of these finite and nonfinite verb structures. By applying sentential rules of structure and meaning, learners gain proficiency in making good use of these verb structures. The extent to which they attained competence level is obvious and is discussed further below in the description of inferential statistics.

\section{1The inferential statistics of the pretest and posttest}

The difference in means between the Pretest and Posttest is: "21.9221 - $86.6164=-64.69434$." The P-value (Probability Value) denoted by "Sig. (2-tailed)" is 0.000 , which is greater than 0.05 . Under the current study, a significant 2 -tailed Prob value 
indicates that there is a significant effect of treatment on the English Language Learners' Overall English Language Competence. As can be seen from the results, there is a significant difference between the Mean Scores of Pretest and Posttest of English Language Learners. In this vein, we reject the Null Hypothesis and accept the Alternate Hypothesis.

\section{Conclusion}

The study's goal was to reject the hypothesis that there was no significant difference between pretest and posttest scores. The Probability Value $(P=.000)$ demonstrated that the Null hypothesis was completely rejected and the Alternate Hypothesis was acknowledged. It meant that the English Language Learners did exceptionally well following the teaching intervention. After administering and evaluating the pretest, the researcher discovered that the English Language Learners were not fully conversant with the understanding of Finite and Nonfinite Verb Structures. They did not understand the terms and their further types.

- $\quad$ They were completely unfamiliar with the variables under investigation.

- They had no comprehensive understanding of the application of verb structures, whether morphologically, syntactically, or semantically.

- Whatever they did in the test was the result of years of the repeated drill, consciously or unconsciously.

- The result of the test was appalling and unacceptable, with the only genius doing a little better and the rest of the lot failing miserably to produce a commendable result.

The current study reveals the reality that English Language Learners require the sentence structure rules to fully command the language. Otherwise, they will not be able to learn it well. This research will undoubtedly benefit PhD and MPhil students and English Language Learners. It will raise educators' awareness of finite and non-finite Verb Structures and investigate the pitfalls in understanding these structures and provide treatment to English Learners so that they can better understand these structures morphologically, grammatically, and grammatically thus semantically. Following treatment, learners will be in a better position to observe these structures, use them in sentences, and consequently comprehend the significance of the sentence appropriately. There is no other part of this research except for Finite and Non-finite Verbs Structures; since verbs in the English language have many dimensions, we could look at them from any point of view we choose. The verb in the sentence serves as the main idea of the topic's spotlight, but one cannot claim to fully comprehend the subject with this current study. A very strong argument exists that the researchers should consider looking into other characteristics of the verb before they accept or reject the study's results. If there is more work done on verb's other dimensions, a greater supply of linguistic knowledge will be available to ESL learners

\section{References}

[1] Aziz, N. (2018). Method of Teaching English Teacher Education Perspective. Lahore: Kashif Mukhtar MAJEED BOOK DEPOT Urdu Bazaar Lahore, Pakistan.

[2] Babbie, E. (1998). The Practice of Social Research (8th ed.). Detroit: Wordsworth Publishing Company. Retrieved 2019

[3] Bauer, L. (2003). Introducing Linguistic Morphology (Second Edition ed.). Edingham University Press.

[4] Chomsky, N. (1965). ASPECTS OF THE THEORY OF SYNTAX. Massachusetts: The M.I.T. Press, Massachusettes Institute of Technology, Cambridge.

[5] Close, R. (1977). A Reference Grammar of Students of English, London: Longman Group LTD.

[6] Eunson, B. (n.d.). Oxford Modern English Grammar Communicating in the 21st Century.

[7] Feignebaum, I. (1985). The Grammar Handbook, New York. Oxford University Press.

[8] Gruyter, M. d. (2006). The Grammar of the English Verb Phrase (Vol. Volume 1 The Grammar of the English Tense Phrase). (B. K. Traugott, Ed.) Berlin-New York: Walter de Gruyter GmbH \& Co. KG, 10785 Berlin.

[9] Halliday, M. (n.d.). An Introduction to Grammar. London: Arnold, 1994.

[10] Hopins, K. (1990). Educational and Psychological Measurement 1990 (A Book on Educational Matters).

Infinitives. (n.d.). Retrieved 14th April Saturday, 2018, from Education First, https/www.ef.edu/english-resources/english-grammar/infinitive

[11] Infinitives. (n.d.). Retrieved 3rd April Sunday, 2018, from Purdue OWL, owl. english.purdue.edu/owl/resource/627/03/

[12] Jonker, J. (2010). The Essence of Research Methodology (A Concise Guide for Master and Ph. D Students in Management Science). London: Springer-Verlag Berlin Heidelberg 2010.

[13] Kim, P. S.-B. (March 02, 2007). English Syntax: An Introduction (First ed.).

[14] Lieber, R. (2004). Morphology and Lexical Semantics. New York: Cambridge University Press.

[15] Malik, P. M. (2010-11). Language and Linguistics on Target (First Edtion ed.). (K. Shahzad, Ed.) Pakistan: New Kitab Mehal 08-Urdu Bazar Lahore.

[16] Masood, R. A. (2019). Leading Bright English Grammar\&Composition: Secondary School English Learners (2nd ed.). (M. N. Tahir, Ed.) Bright Publications Urdu Bazar Lahore.

[17] Muanwar, M. (2016). AN APPROACH TO THE STUDY OF LINGUISTICS. Lahore: New Kitab Mehal, 08 Urdu Bazar Lahore, Pakistan.

[18] Pandey, P. P. (2015). Research Methodology: Tools and Techniques. Buzau: Bridge Centre Buzau, Al. Margilloman 245 bis, 120082.

[19] Participles - Present, Past, and Perfect. Lingolia. (n.d.). Retrieved from https:// english.lingolia.com/en/grammar/verbs/participles

[20] PTB. (2019). English Book-1(Short Stories) for Intermediate Students. Lahore: Punjab Textbook Board.

[21] Rasheed, A. .. (2013-12). Bright English FOR 10th Class. Lahore: Bright Publications, Urdu Bazar Lahore.

[22] Rasheed, A. (2013-14). Bright English for 9th Class. Lahore: Bright Publications Urdu Bazar, Lahore.

[23] Swan, M. (2014). Oxford English Grammar Course. Glasgow: Gabbes \& Grosset, an imprint of Gresham Publishing Company Ltd. 
[24] Use of The Bare Infinitives. (n.d.). Retrieved 14th April Saturday, 2018, from English Grammar, www.englishgrammar.org/bare-infinitives -2 [25]Walliman, N. (2011). RESEARCH METHODS THE BASICS. USA \& Canada: Routledge, 2 Park Square Milton Park Abingdon Oxon OX14 4RN.

[26] Woodham, R. (n.d.). Dare and Need Auxiliary Verb? BBC World Service. Retrieved 26 May 2018, from www.bbc.co.uk/world service/learningenglish/grammar/learnit/learnitv274.shtml

[27] Zoltan, D. (2007). Research Method in Applied Linguistics, 2077. Oxford: OXFORD UNIVERSITY PRESS. 